\title{
Effect of varying dietary supplemental inclusion levels of onion and garlic on semen quality characteristics of Hubbard white breeder broiler cocks aged 35-41 weeks old
}

\author{
Okoro V.M.O. ${ }^{* 1,2}$, Nwokeocha A.C.C. ${ }^{2}$, Ijezie C.O. ${ }^{2}$, Mbajiorgu C.A. ${ }^{1}$ and E.F. Mbajiorgu ${ }^{3}$ \\ ${ }^{1}$ Department of Agriculture and Animal Health, University of South Africa, \\ Florida science campus, P.O BOX 392, UNISA, 0003, South Africa. \\ Received: 05-12-2015 \\ Accepted: 17-02-2016
}

\begin{abstract}
An experiment was conducted to determine the effect of varying dietary supplemental inclusion levels of onion and garlic on semen quality characteristics of Hubbard white breeder broiler cocks aged 35-41 weeks old. A complete randomized design was used for the experiment. The three dietary supplemental levels based on garlic and onion supplemental inclusion levels are $\mathrm{L}_{0}\left(0 \mathrm{~g}\right.$ onion and $0 \mathrm{~g}$ garlic per $600 \mathrm{~g}$ DM feed), $\mathrm{L}_{1},(2.5 \mathrm{~g}$ onion and $2.5 \mathrm{~g}$ garlic per $600 \mathrm{~g}$ DM feed $)$ and $\mathrm{L}_{3}(5 \mathrm{~g}$ Onion and $5 \mathrm{~g}$ garlic per $600 \mathrm{~g}$ DM feed) with each treatment having 3 replicates. A quadratic type equation was used to determine the Onion and Garlic levels for optimum semen quality characteristics. Daily supplementation with $2.5 \mathrm{~g}$ onion and $2.5 \mathrm{~g}$ garlic per $600 \mathrm{~g} \mathrm{DM}$ feed increased $(\mathrm{P}<0.05)$ actual life sperm count $(\times 10 \mathrm{v} / \mathrm{nl})$ by $370.58 \%$ whereas daily supplementation with $5 \mathrm{~g}$ onion and $5 \mathrm{~g}$ garlic per $600 \mathrm{~g}$ DM feed increased $(\mathrm{P}<0.05)$ actual life sperm count $(\times 10 \mathrm{v} / \mathrm{nl})$ by $405.75 \%$. Similarly, daily supplementation with $2.5 \mathrm{~g}$ onion and $2.5 \mathrm{~g}$ garlic per $600 \mathrm{~g}$ DM feed increased $(\mathrm{P}<0.05)$ live sperm count (\%) by $399.88 \%$ whereas daily supplementation with $5 \mathrm{~g}$ onion and $5 \mathrm{~g}$ garlic per $600 \mathrm{~g}$ DM feed increased $(\mathrm{P}<0.05)$ live sperm count $(\%)$ by $379.90 \%$. Dietary onion and garlic supplemental inclusion levels of $3.335 \mathrm{~g}, 3.446 \mathrm{~g}$, $3.787 \mathrm{~g}, 3.438 \mathrm{~g}, 3.068 \mathrm{~g}, 4.247 \mathrm{~g}$ per $600 \mathrm{~g}$ DM feed supported optimum actual dead sperm count, dead sperm count, actual live sperm count, live sperm count (\%), acrosome morphology defects (\%), acrosome detachment (\%) with probability values ranging from 0.018 to 0.906 , whereas minimum Acrosome abnormality (\%) reduction was achieved at an optimum supplementation level of $3.58 \mathrm{~g}$ per $600 \mathrm{~g}$ DM feed with $\mathrm{Y}=3.33-1.332 \mathrm{x}+0.186 \mathrm{x}^{2}, \mathrm{r}^{2}=0.680$, P-value $=0.018$. These findings show that onion and garlic supplementation enhances semen quality characteristics in Hubbard white breeder broiler cocks.
\end{abstract}

Key words: Garlic, Hubbard, Onion, Quadractic function, Semen, Supplemental inclusion.

\section{INTRODUCTION}

One of the major issues on breeding in farm animals is infertility and approximately $30 \%$ of the problems are related to the males (Khaki et al. 2009; Lee et al. 2012; Barkhordari et al. 2013). Recently, a wide number of plantderived pharmaceutical products are now being used in traditional medicine because of their beneficial properties in handling infertility (Yama et al., 2011). Hassanpour et al. (2011) noted that some plants such as Allium species are rich source of a wide variety of secondary metabolites such as flavonoids, tannins, trepenoids, and alkaloids among others. The edible Allium species - garlic (Allium sativum. L.) and onion (Allium cepa .L.) have long been used as food ingredients and medicine (Atmaca, 2003; Durani et al., 2010; Kim et al., 2011). Khaki et al, (2009, 2012) observed that numerous health benefits have been identified which attract researchers to investigate the validity of medical properties of these plants. He further stated that anti oxidative properties of aqueous onion juice have been proved in studies conducted on animals where fresh onion juice has a positive effect on the sperm health and spermatogenesis in rats (Khaki et al. 2012).

Over the years, maintenance of fertile cocks in most poultry breeding farms has been difficult in hot humid tropical environments. Cocks with high semen producing capacity are often few and they degenerate due to changes in factors such as age, poor nutrition, and unfavorable climatic conditions and poor management. For good results in the artificial insemination of chickens, the quality of semen should be ensured (Alkan et al., 2002). The importance of semen evaluation in poultry breeding for selection of breeding males or for routinely monitoring their reproductive performance are well recognized (Cheng et al., 2002). Fertilizing ability of the semen can be accessed by its motility, live/dead sperm and morphological evaluations. The semen collector can also improve on semen quality by ensuring

*Corresponding author's e-mail:okorovm@unisa.ac.za. ${ }^{2}$ Department of Animal Science and Technology Federal University of Technology, Owerri, Nigeria. ${ }^{3}$ School of Anatomical Sciences, Faculty of Health Sciences, University of Witwatersrand. 
non contamination of semen with faeces, urine and or blood during semen collection at ejaculation (Alkan et al., 2002). It is therefore very important to know the proportion of abnormal spermatozoa in a semen sample in order to determine the best semen characteristics for optimum fertility (Alkan et al., 2002). This research is aimed at identifying the effect of supplemental inclusion levels of Garlic and Onion on semen quality characteristics of Hubbard White breeder cocks as well as identifies the optimal supplemental inclusion levels of garlic and onions as semen quality enhancers in Hubbard White breeder cock diets aged between 35-41 weeks of age.

\section{MATERIALS AND METHODS}

This study was conducted at the Federal University of Technology, Owerri Teaching and Research farm in Nigeria. The breeder cocks were obtained from Crown Feeds and Livestock Nigeria Limited, Isseleuku Delta State, Nigeria; a breeder farm that hatches and sells broiler and layer day old chicks. Garlic and onion supplementation is a routine management practice in the farm, which is usually given to the cocks in minute quantities without gradation and fixed level of inclusion. This research was therefore aimed at subjecting this management practice to experimentation in order to ascertain the effects of garlic and onion inclusion levels on semen quality characteristics of Hubbard breeder cocks as well as determine optimum inclusion levels. A total of 27 cocks with average bodyweight of $3.84 \mathrm{~kg}$, and aged from $35-41$ weeks old (from start to end of experiment) were acquired from the breeder farm at a subsidized rate. They were assigned to 3 experimental groups, with each group having 3 replicates and 3 birds per replicate. Fresh Allium cepa (onion) and Allium sativum (garlic) were bought from open market at Owerri, Nigeria. The fresh A. cepa and A. sativum were then peeled, crushed and incorporated in the test diets at the given levels of inclusion below:

$\mathrm{T}(\mathrm{CONTROL})=0 \mathrm{~g}$ A. cepa $+0 \mathrm{~g}$ A. sativum $+600 \mathrm{~g}$ feed $/ \mathrm{kgDM}$ $\mathrm{T},=2.5 \mathrm{~g}$ A. cepa $+2.5 \mathrm{~g}$ A. sativum $+600 \mathrm{~g}$ feed $/ \mathrm{kgDM}$ $\mathrm{T} f=5 \mathrm{~g}$ A. cepa $+5 \mathrm{~g}$ A. sativum $+600 \mathrm{~g}$ feed $/ \mathrm{kgDM}$

A commercial grower mash was used to feed the birds during the first one week of adaptation. Thereafter the inclusion of garlic and onion into $600 \mathrm{~g}$ of commercial grower feed (with nutrient composition shown in Table 1) per

TABLE 1: Nutrient Composition of the experimental diet

\begin{tabular}{lccc}
\hline Nutrient & \multicolumn{3}{c}{ Diet } \\
\cline { 2 - 4 } & $\mathrm{L}_{0}$ & $\mathrm{~L}_{1}$ & $\mathrm{~L}_{2}$ \\
\hline Dried Matter (g/kg) & 882 & 881 & 880 \\
Energy (MJ/kg DM feed) & 190 & 190 & 190 \\
Crude protein (g/kg DM) & 220 & 220 & 220 \\
Total G+O (g/kg DM) & 0.00 & 5 & 10 \\
Total G+O to Energy ratio & 0.00 & 0.026 & 0.053 \\
Total G+O to CP ratio & 0.00 & 0.023 & 0.045 \\
\hline
\end{tabular}

replicate was given to the birds. Water was provided adlibitum throughout the experimental period to the animals.

\section{Semen collection}

Semen was collected from all the cocks in each replicate using abdominal massage technique (Lake, 1957) and evaluated for semen quality characteristics. The collection was made once every two weeks for 3 collections, by the abdominal massage method between 7.00am and $10.00 \mathrm{am}$ in the morning and in the month of June and July being the peak of rainy season in Nigeria. The abdominal massage techniques involved massaging of the cloacal region to achieve phallic tumescence, followed by a cloacal stroke, a squeezing of the region surrounding the sides of the cloaca to express the semen. The semen was then milked down by firm finger pressure on either side of the vent into the labeled collecting tube.

\section{Semen evaluation}

Semen Volume: The volume of semen was measured when it had been milked down into the graduated collecting glass test tubes. Coloured semen which is not pure white in colour was discarded as it might have been contaminated by faeces or blood.

Semen pH: The pH of the fresh semen samples of each cockerel was measured with the aid of litmus paper (MediTest Combi $9^{\mathrm{TM}}$ ), by dropping the sample on the paper and the $\mathrm{pH}$ read off.

Sperm viability (Progressive, Non Progressive and Immotile sperm cells percentages): This was assessed from the diluted semen (1:250) of modified Ringer's solution to a standard solution (Martin, 2004) and examined. One drop of the diluted semen was placed on the slide and covered with glass cover. Motility was estimated by microscopic observation (400 x magnification). Motility was expressed as the percentage of motile spermatozoa with moderate to rapid progressive forward movements in large circles, while non progressive are those with low to moderate progressive, on the spot twitching movement and Immotile were non moving spermatozoans. At least 15 microscopic fields were examined for each sample.

Sperm concentration: The concentration of sperm cells is expressed as the number of cells per cubic centimeter of semen. The concentrations of sperm cells were determined with a hemocytometer after the semen had been diluted to a standard volume.

Sperm vitality assessment (live and dead percentage): A drop of semen with the aid of a micropipette was placed on a microscope slide, and a drop of eosin-negrosin stain was added and smeared and air dried immediately and viewed under microscope at $\times 400$ magnifications. The proportions of live (eosin-impermeable) and dead (eosin-permeable) spermatozoa in a sample were assessed on the basis of 300 cells counted. 
Vol. Issue, ()

Sperm vitality assessment (Actual live and Actual dead sperm count): This was estimated from the total sperm count assessed from each individual in relation to the percentage live and dead sperm count.

Sperm acrosome morphology and defects: Morphology was examined in smears stained with eosin and nigrosin. At each preparation 300 cells were counted and the percentage of various defects calculated. Hence the morphological defects of acrosome, detached, swollen and abnormality was evaluated. The acrosomal morphology defects were then categorized into three classes:

a) Detached acrosome (characterized by presence of acrosome with separated head, neck and tail).

b) Swollen acrosome (characterized by acrosome with swollen and ruffled apical ridge and neck).

c) Acrosome abnormality (characterized by presence of acrosome with irregular shaped head).

Statistical analysis: Data generated were analyzed by one way analysis of variance (SAS 2008). Where there was a significant F-test $(\mathrm{P}<0.05)$, the least significant difference (LSD) method was used to separate the means (SAS, 2008). The significant affected responses will be modeled using the following quadratic equation (SAS, 1994):

$$
\mathrm{Y}=\mathrm{a}+\mathrm{b}_{1} \mathrm{x}+\mathrm{b}_{2} \mathrm{x}^{2}+\mathrm{e}
$$

Where $Y=$ Semen Quality Characteristics; $a=$ intercept on Y-axis; $b=$ coefficients of the quadratic equation, $x=$ Inclusion ratio of onion and garlic estimated as $-b_{1} / 2 b_{2}$, which is the value of $x$ that gives the optimum inclusion level. The quadratic model was fitted to the experimental data by means of the Non-linear model (NLIN) procedure of SAS (SAS, 2008). The quadratic model was used because it gave the best fit.

\section{RESULTS AND DISCUSSION}

Results of the nutrient composition of the experimental diet are presented in Table 1 . The experimental diets contained between 880 to $882 \mathrm{~g} \mathrm{DM} / \mathrm{kg}$ feed, $190 \mathrm{MJ}$ energy $/ \mathrm{kg}$ DM feed, $220 \mathrm{~g}$ protein $/ \mathrm{kg}$ DM feed but with different supplemental inclusion levels of onion and garlic of $2.5 \mathrm{~g}$ Onion and $2.5 \mathrm{~g}$ garlic per $600 \mathrm{~g}$ DM feed and $5 \mathrm{~g}$ onion and $5 \mathrm{~g}$ garlic per $600 \mathrm{~g}$ DM feed, respectively. The results of the inclusion levels of onion and garlic on semen characteristics of Hubbard white breeder cocks aged 35-41 weeks are presented in Table 2. There were significant effect $(\mathrm{P}<0.05)$ of onion and garlic supplemental inclusion levels on Actual Dead Sperm Count $(\times 10 \mathrm{v} / \mathrm{nl})$, Dead Sperm Count $(\%)$, Actual Live Sperm count ( $\times 10 \mathrm{v} / \mathrm{nl})$, Live Sperm (\%), Acrosome Morphology Defects (\%), Acrosome detachment $(\%)$ and Acrosome abnormality (\%), while there was no effect $(\mathrm{P}>0.05)$ on other parameters studied. Daily supplementation with $2.5 \mathrm{~g}$ onion and $2.5 \mathrm{~g}$ garlic per $600 \mathrm{~g}$ DM feed reduced $(\mathrm{P}<0.05)$ actual dead sperm count $(\times 10 \mathrm{v} / \mathrm{nl})$ by $80.5 \%$ whereas daily supplementation with $5 \mathrm{~g}$ onion and $5 \mathrm{~g}$ garlic per $600 \mathrm{~g}$ DM feed reduced $(\mathrm{P}<0.05)$ actual dead sperm count $(\times 10 \mathrm{v} / \mathrm{nl})$ by $73.2 \%$ in Hubbard white broiler breeder cock (Table 3). Similarly, daily supplementation with $2.5 \mathrm{~g}$ onion and 2.5g garlic per 600g DM feed reduced $(\mathrm{P}<0.05)$ actual dead sperm count $(\times 10 \mathrm{v} / \mathrm{nl})$ by $79.99 \%$ whereas daily supplementation with $5 \mathrm{~g}$ onion and $5 \mathrm{~g}$ garlic per $600 \mathrm{~g}$ DM feed reduced $(\mathrm{P}<0.05)$ actual dead sperm count $(\times 10 \mathrm{v} / \mathrm{nl})$ by $75.99 \%$ in Hubbard white breeder cock (Table 3 ). Daily supplementation with $2.5 \mathrm{~g}$ Onion and $2.5 \mathrm{~g}$ garlic per $600 \mathrm{~g}$ DM feed increased significantly $(\mathrm{P}<0.05)$ actual life sperm count $(\times 10 \mathrm{v} / \mathrm{nl})$ by $370.58 \%$ whereas daily supplementation with $5 \mathrm{~g}$ onion and $5 \mathrm{~g}$ garlic per $600 \mathrm{~g}$ DM feed increased $(\mathrm{P}<0.05)$ actual life sperm count $(\times 10 \mathrm{v} / \mathrm{nl})$ by $405.75 \%$ in Hubbard white breeder cock (Table 3 ). In the same manner,

TABLE 2: Effect of Garlic and Onion supplementation on semen characteristics of Hubbard breeder cocks Semen characteristics

\begin{tabular}{|c|c|c|c|c|}
\hline & \multicolumn{4}{|c|}{ Diet } \\
\hline & $\mathrm{L}_{0}$ & $\mathrm{~L}_{1}$ & $\mathrm{~L}_{2}$ & SE \\
\hline Sperm Volume $(\mathrm{ml})$ & 0.467 & 0.533 & 0.40 & 0.114 \\
\hline Sperm pH & 8.00 & 7.67 & 8.00 & 0.385 \\
\hline \multicolumn{5}{|l|}{ Sperm Viability } \\
\hline Progressive Motile cells (\%) & 13.33 & 12.67 & 16.00 & 7.293 \\
\hline Non Progressive Motile cells (\%) & 3.33 & 4.00 & 3.33 & 2.073 \\
\hline Immotile sperm cells $(\%)$ & 83.33 & 83.33 & 81.67 & 9.280 \\
\hline Sperm Count $(\times 10 \mathrm{v} / \mathrm{nl})$ & 68.33 & 66.67 & 75.00 & 2.722 \\
\hline Actual Dead Sperm Count $(\times 10 v / n l)$ & $56.50^{\mathrm{a}}$ & $11.00^{\mathrm{b}}$ & $15.11^{\mathrm{b}}$ & 5.733 \\
\hline Dead Sperm Count $(\%)$ & $83.33^{\mathrm{a}}$ & $16.67^{\mathrm{b}}$ & $20.00^{\mathrm{b}}$ & 9.230 \\
\hline Actual Live Sperm count $(\times 10 v / n l)$ & $11.83^{\mathrm{b}}$ & $55.67^{\mathrm{a}}$ & $59.83^{\mathrm{a}}$ & 6.476 \\
\hline Live Sperm $\operatorname{count}(\%)$ & $16.67^{\mathrm{b}}$ & $83.33^{\mathrm{a}}$ & $80.00^{\mathrm{a}}$ & 9.230 \\
\hline \multicolumn{5}{|l|}{ Sperm Morphology } \\
\hline Acrosome Morphology Defects(\%) & $82.67^{\mathrm{a}}$ & $70.00^{\mathrm{b}}$ & $72.00^{\mathrm{b}}$ & 2.735 \\
\hline Acrosome detachment $(\%)$ & $76.33^{\mathrm{a}}$ & $62.00^{\mathrm{b}}$ & $57.67^{\mathrm{b}}$ & 3.156 \\
\hline Acrosome swelling (\%) & $3.00^{\mathrm{b}}$ & $8.00^{\mathrm{ab}}$ & $13.00^{\mathrm{a}}$ & 1.491 \\
\hline Acrosome abnormality (\%) & $3.33^{\mathrm{a}}$ & $0.001^{\mathrm{b}}$ & $1.33^{\mathrm{ab}}$ & 0.720 \\
\hline
\end{tabular}

${ }_{\mathrm{a}, \mathrm{b}}$ Means in the same row with different superscripts are significantly different $(\mathrm{P}<0.05)$ 
daily supplementation with $2.5 \mathrm{~g}$ onion and $2.5 \mathrm{~g}$ garlic per $600 \mathrm{~g}$ DM feed increased $(\mathrm{P}<0.05)$ life sperm count $(\%)$ by $399.88 \%$ whereas daily supplementation with $5 \mathrm{~g}$ onion and $5 \mathrm{~g}$ garlic per $600 \mathrm{~g}$ DM feed increased $(\mathrm{P}<0.05)$ life sperm count (\%) by $379.90 \%$ in Hubbard white breeder cock (Table 3 ). Daily supplementation with $2.5 \mathrm{~g}$ onion and $2.5 \mathrm{~g}$ garlic per 600g DM feed reduced $(\mathrm{P}<0.05)$ acrosome morphology defects (\%) by $15.33 \%$ whereas daily supplementation with $5 \mathrm{~g}$ onion and $5 \mathrm{~g}$ garlic per $600 \mathrm{~g}$ DM feed reduced $(\mathrm{P}<0.05)$ acrosome morphology defects (\%) by $12.91 \%$ in Hubbard white breeder cock (Table 3). Daily supplementation with $2.5 \mathrm{~g}$ onion and $2.5 \mathrm{~g}$ garlic per $600 \mathrm{~g}$ DM feed reduced $(\mathrm{P}<0.05)$ acrosome detachment $(\%)$ by $18.77 \%$ whereas daily supplementation with $5 \mathrm{~g}$ onion and $5 \mathrm{~g}$ garlic per $600 \mathrm{~g}$ DM feed reduced $(\mathrm{P}<0.05)$ acrosome detachment $(\%)$ by 24.45 $\%$ in Hubbard white breeder cock. Daily supplementation with $2.5 \mathrm{~g}$ onion and $2.5 \mathrm{~g}$ garlic per $600 \mathrm{~g}$ DM feed reduced $(\mathrm{P}<0.05)$ acrosome abnormality $(\%)$ by $99.97 \%$ whereas daily supplementation with $5 \mathrm{~g}$ onion and $5 \mathrm{~g}$ garlic per $600 \mathrm{~g}$ DM feed reduced $(\mathrm{P}<0.05)$ acrosome abnormality $(\%)$ by $60.06 \%$ in Hubbard white breeder cock (Table 3). Dietary onion and garlic supplemental inclusion levels of $3.335 \mathrm{~g}$, $3.446 \mathrm{~g}, 3.787 \mathrm{~g}, 3.438 \mathrm{~g}, 3.068 \mathrm{~g}, 4.247 \mathrm{~g}$ per $600 \mathrm{~g}$ DM feed supported optimum Actual Dead Sperm Count $(\times 10 \mathrm{v} / \mathrm{nl})$, Dead Sperm Count $(\%)$, Actual Live Sperm count $(\times 10 \mathrm{v} /$ $\mathrm{nl})$, Live Sperm (\%), Acrosome Morphology Defects (\%), Acrosome detachment $(\%)$ with probability values ranging from 0.018 to 0.906 whereas minimum Acrosome abnormality (\%) reduction was achieved at an optimum onion and garlic supplementation level of $3.58 \mathrm{~g}$ per $600 \mathrm{~g}$ DM feed with $Y=3.33-1.332 x+0.186 x^{2}, r^{2}=0.680, P$-value $=0.018$ (Table 4).

Hafez and Hafez (2000) reported a semen volume and $\mathrm{pH}$ ranging from $0.2-0.5 \mathrm{ml}$, and 7.2-7.6 in domestic cockerels. However values reported in this study ranged from $0.40-0.53 \mathrm{ml}$ for semen volume and 7.67-8.00 for semen $\mathrm{pH}$. This shows a little variation which could be accounted for because the cocks were adult birds. However various factors had been reported that accounts for wide variation in semen quality characteristics of birds, like breed (Peters et al., 2008), strain (Murugesan et al., 2013) and line (Tarif et al., 2013). The semen quality parameters reported for different breed like White Leghorn (Elagib etal., 2012), Plymouth Rock (Tarif, 2013), Rhode Island Red( RIR) (Kabir et al., 2007) and indigenous roosters (Ajayi et al., 2011) demonstrated high degree of variation. The environmental factors having influence on semen quality are climate (Saeed et al., 1975), time of collection (Egbunike et al., 1979), frequency of collection (Riaz et al., 2004) and nutrition (Kabir et al., 2007). Additionally, the high concentration of immotile sperm cells in this study ranging from 81.67 $83.33 \%$ of total viable spermatozoa shows that it is very high. This could be as a result of a high morphological defects also recorded in this study, as Alkan et al., (2002) reported that morphological defect types of turkey and cock semen

TABLE 3: Percentage Effect of Dietary Supplementation of Garlic and Onion inclusion levels on significant parameters in Hubbard white breeder cocks.

\begin{tabular}{lcr}
\hline & \multicolumn{2}{c}{ Percentage increase due to supplementation } \\
\cline { 2 - 3 } Significant Parameters & $2.5 \mathrm{~g}$ Onion and 2.5g Garlic & $5 \mathrm{~g}$ Onion and 5g Garlic \\
\hline Actual Dead Sperm Count $(\times 10 \mathrm{v} / \mathrm{nl})$ & $80.50 \%$ & $73.26 \%$ \\
Dead Sperm Count $(\%)$ & $79.90 \%$ & $75.99 \%$ \\
Actual Live Sperm count $(\times 10 \mathrm{v} / \mathrm{nl})$ & $370.58 \%$ & $405.75 \%$ \\
Live Sperm count $(\%)$ & $399.88 \%$ & $379.90 \%$ \\
Sperm Morphology & & \\
Acrosome Morphology Defects $(\%)$ & $15.33 \%$ & $12.91 \%$ \\
Acrosome detachment $(\%)$ & $18.77 \%$ & $24.45 \%$ \\
Acrosome swelling (\%) & $166.67 \%$ & $333.33 \%$ \\
Acrosome abnormality (\%) & $99.97 \%$ & $60.06 \%$ \\
\hline
\end{tabular}

TABLE 4: Optimal Inclusion of Garlic + Onion on Semen quality characteristics of Hubbard White Breeder Cocks based on Quadratic function of Regression Analysis.

\begin{tabular}{llccc}
\hline Traits & Quadratic function & $\begin{array}{c}\text { Optimal \% G+O } \\
\text { inclusion level }\end{array}$ & $\begin{array}{c}\mathrm{r}^{2} \text { value } \\
\text { Probability } \\
\text { values }\end{array}$ \\
\hline Actual Dead Sperm Count $\left(10^{6}\right)$ & $\mathrm{Y}=54.665-12.452 \mathrm{x}+1.867 \mathrm{x}^{2}$ & 3.335 & 0.154 & 0.777 \\
Dead Sperm Count (\%) & $\mathrm{Y}=80.00-18.332 \mathrm{x}+2.66 \mathrm{x}^{2}$ & 3.446 & 0.172 & 0.754 \\
Actual Live Sperm count $\left(10^{6}\right)$ & $\mathrm{Y}=13.665+11.618 \mathrm{x}-1.534 \mathrm{x}^{2}$ & 3.787 & 0.175 & 0.750 \\
Live Sperm (\%) & $\mathrm{Y}=20.0+18.332 \mathrm{x}-2.66 \mathrm{x}^{2}$ & 3.438 & 0.172 & 0.754 \\
Acrosome Morphology Defects (\%) & $\mathrm{Y}=82.0-2.70 \mathrm{x}+0.44 \mathrm{x}^{2}$ & 3.068 & 0.063 & 0.906 \\
Acrosome detachment (\%) & $\mathrm{Y}=73.0-2.497 \mathrm{x}+0.279 \mathrm{x}^{2}$ & 4.247 & 0.100 & 0.849 \\
Acrosome swelling (\%) & $\mathrm{Y}=5.665+0.736 \mathrm{x}+0.053 \mathrm{x}^{2}$ & -6.943 & 0.500 & 0.035 \\
Acrosome abnormality (\%) & $\mathrm{Y}=3.33-1.332 \mathrm{x}+0.186 \mathrm{x}^{2}$ & 3.581 & 0.680 & 0.018 \\
\hline
\end{tabular}


are similar and the most frequent defects are observed at the acrosome and mid-piece, suggesting that these organelles are the most susceptible to environmental factors and influence semen viability. However, the values of progressive motile cells were inconsistent with the level of onion and garlic supplementation used in the present study. Also, the sperm count which tended to lie slightly above the range of $30-70\left(x 10^{6} / \mathrm{nl}\right)$ as reported by Hafez and Hafez (2000) is not significantly influenced by increased inclusion of onion and garlic.

Results from the present study indicated that there were significant effect $(\mathrm{P}<0.05)$ of onion and garlic supplemental inclusion levels on Actual Dead Sperm Count $(\times 10 \mathrm{v} / \mathrm{nl})$, Dead Sperm Count $(\%)$, Actual Live Sperm count $(\times 10 \mathrm{v} / \mathrm{nl})$, Live Sperm (\%), Acrosome Morphology Defects (\%), Acrosome detachment (\%) and Acrosome abnormality (\%). These findings suggest that these sperm reproductive parameters were first and foremost influenced by the range of onion and garlic supplemental inclusion levels used in the present study and hence, these parameters attempt, as a priority, to respond and adjust to the onion and garlic supplemental levels. This is confirmed by the results obtained in which daily supplementation with $2.5 \mathrm{~g}$ onion and $2.5 \mathrm{~g}$ garlic per $600 \mathrm{~g}$ DM feed reduced $(\mathrm{P}<0.05)$ actual dead sperm count by $80.5 \%$ whereas daily supplementation with $5 \mathrm{~g}$ onion and $5 \mathrm{~g}$ garlic per $600 \mathrm{~g}$ DM feed reduced $(\mathrm{P}<0.05)$ actual dead sperm count $(\times 10 \mathrm{v} / \mathrm{nl})$ by $73.2 \%$ in Hubbard white breeder boiler cocks (Table 3). Similarly, daily supplementation with $2.5 \mathrm{~g}$ onion and $2.5 \mathrm{~g}$ garlic per $600 \mathrm{~g}$ DM feed reduced $(\mathrm{P}<0.05)$ actual dead sperm count $(\%)$ by $79.99 \%$ whereas daily supplementation with $5 \mathrm{~g}$ onion and $5 \mathrm{~g}$ garlic per $600 \mathrm{~g}$ DM feed reduced $(\mathrm{P}<0.05)$ actual dead sperm count $(\times 10 \mathrm{v} / \mathrm{nl})$ by $75.99 \%$ in Hubbard white breeder broiler cocks (Table 3 ). Daily supplementation with $2.5 \mathrm{~g}$ onion and $2.5 \mathrm{~g}$ garlic per $600 \mathrm{~g}$ DM feed increased $(\mathrm{P}<0.05)$ actual life sperm count $(\times 10 \mathrm{v} / \mathrm{nl})$ by $370.58 \%$ whereas daily supplementation with $5 \mathrm{~g}$ onion and $5 \mathrm{~g}$ garlic per $600 \mathrm{~g}$ DM feed increased $(\mathrm{P}<0.05)$ actual life sperm count $(\times 10 \mathrm{v} / \mathrm{nl})$ by $405.75 \%$ in Hubbard white breeder cock. Thus, one possible consequence of these responses to dietary supplemental onion and garlic inclusion levels might be the gain of sensitivity to regulate sperm parametric characteristics according to onion and garlic supplemental inclusion levels as observed in the present study. The physiological explanation for the present observation is not clear and merits further observation. However, it is known that some researchers have shown that onion contain exogenous and endogenous antioxidants such as selenium, glutathione, vitamins $\mathrm{A}, \mathrm{B}$ and $\mathrm{C}$ and flavonoids such as quercetin and isorhamnetin (Griffiths et al., 2002). These antioxidants protect DNA and other important molecules from oxidation and damage which would otherwise induce apoptosis, and could improve sperm health parameters, increasing the rate of fertility in men (Hunt et al., 1992, Izawa et al., 2008). Khaki et al (2008) also demonstrated that the administration of onion juice ( $1 \mathrm{~g} / \mathrm{rat} /$ day) for 20 days increases sperm count, viability and motility. The onion fresh juice can significantly increase the recovery of sperm health parameters such as count, motility and serum total testosterone and total antioxidants capacity (Chakrabatt et al., 2003) levels in T. gondii- infected rats (Khaki et al., 2011). On the other hand, garlic has been used as medicine worldwide since ancient times (Arzanlou et al., 2010). It contains a wide variety of phytochemicals and micro components such as trace elements, vitamins, fructans, flavonoids and sulphur compounds which can scavenge free radicals (Khaki et al., 2011). Therefore, importantly, one possible consequence of these ad-libitum combination of onion and garlic in the diet of Hubbard white breeder broiler cocks might be the pulling together of these qualities which invariably influenced and improved the bird's sperm health parameters as well as their semen viability as observed in this study. Therefore, it appears from the result obtained herein that birds would likely benefit practically from adlibitum supplemental combination of onion and garlic in terms of enhancing their sperm health parameters and as such help to improve their reproductive efficiency

Results of the present study indicate that dietary onion and garlic supplemental inclusion levels of $3.335 \mathrm{~g}$, $3.446 \mathrm{~g}, 3.787 \mathrm{~g}, 3.438 \mathrm{~g}, 3.068 \mathrm{~g}, 4.247 \mathrm{~g}$ per $600 \mathrm{~g}$ DM feed supported optimum Actual Dead Sperm Count $(\times 10 \mathrm{v} / \mathrm{nl})$, Dead Sperm Count $(\%)$, Actual Live Sperm count $(\times 10 \mathrm{v} /$ $\mathrm{nl}$ ), Live Sperm (\%), Acrosome Morphology Defects (\%), Acrosome detachment (\%) with probability values ranging from 0.018 to 0.906 whereas minimum Acrosome abnormality (\%) was achieved at an optimum onion and garlic supplementation inclusion level of $3.58 \mathrm{~g}$ per $600 \mathrm{~g} \mathrm{DM}$ feed with $\mathrm{Y}=3.33-1.332 \mathrm{x}+0.186 \mathrm{x}^{2}, \mathrm{r}^{2}=0.680$, P-value $=$ 0.018. Several studies had applied the quadratic regression model to optimize inclusion levels of feed materials on farm animals: Goats (Ogundun et al., 2013), Chicken (Alabi et al., 2014; Mbajiorgu et al., 2011; Mbajiorgu 2011). However none of these studies have reported on optimizing the effect of onion and garlic supplemental inclusion levels on sperm quality characteristics of Hubbard white breeder cocks. In their studies, Ogundun et al., (2013) reported a single optimum value of $25.57 \%$ of uromalt inclusion level for optimizing Average sperm morphology and average sperm abnormality in West African dwarf goats. This is different from the results of the present findings in which differences in optimum requirements of dietary supplemental inclusion levels of onion and garlic needed to optimize different sperm parametric performances were observed in Hubbard white breeder cocks. These differences in optimum supplemental inclusion levels of onion and garlic for optimizing different sperm quality characteristic's in Hubbard white breeder cocks may have been expected since feeds of different dietary compositions would give different optimal performance 
responses (Lin et al., 1980; Buyse et al.1992; Collin et al., 2003). Thus, this study which aligns with previous studies in chickens on the optimum dose response values of dietary nutrient inclusion levels for optimizing different parameters have been dynamic, but trials in which parametric performances were achieved at variable optimal dietary nutrient inclusion levels predominate (Alabi et al., 2014; Mbajiorgu et al., 2011; Mbajiorgu 2011; Sahin et al., 2002). In the present study, onion and garlic supplemental inclusion level for optimum acrosome swelling (\%) was not reached. It is possible that onion and garlic supplemental inclusion level required for optimum acrosome swelling (\%) in this study was higher than the range of values used in the study. However, results showed that minimum acrosome abnormality (\%) reduction was achieved at an optimum onion and garlic supplementation level of $3.58 \mathrm{~g}$ per $600 \mathrm{~g}$ DM feed with $\mathrm{Y}=3.33-1.332 \mathrm{x}+0.186 \mathrm{x}^{2}, \mathrm{r}^{2}=0.680, \mathrm{P}$-value $=0.018$. This suggests that this inclusion level of $3.58 \mathrm{~g}$ per $600 \mathrm{~g}$ DM feed could ensure production of mature and viable spermatozoa and hence could support reproductive efficiency in Hubbard white breeder cocks. Importantly, the sharp increase in sperm abnormalities above this optimum onion and garlic inclusion value of $3.58 \mathrm{~g}$ (figure. 1) tended to indicate that spermatogenic process was affected by this slight detrimental percentage increase in onion and garlic inclusion level and could probably be attributed to high spermicidal effect of the test ingredient as the level of supplementation increases. Thus it is clear from the results herein that onion and garlic supplemental levels above $3.58 \mathrm{~g}$ per $600 \mathrm{~g}$ DM feed in the diet of Hubbard white breeder broiler cocks will increase sperm abnormalities and will have important consequences on the quality of the spermatozoa and fertility of the Hubbard cocks. These findings have a lot of implications on the use of supplemental onion and garlic inclusion levels to enhance reproductivity efficiency in Hubbard white breeder broiler cocks. No previous study on this issue regarding Hubbard white breeder broiler cocks was found.

\section{CONCLUSION}

Supplemental inclusion of onion and garlic in diets of Hubbard white breeder cocks significantly affected $(\mathrm{P}<0.05)$ their semen count, viability and morphology. Daily supplementation with $3.335 \%, 3.446 \%, 3.787 \%$, 3.438\%, $3.068 \%, 4.247 \%$ and $3.581 \%$ onion and garlic each respectively, supported optimum actual dead sperm count $(\times 10 \mathrm{v} / \mathrm{nl})$, dead sperm count $(\%)$, actual live sperm count $(\times 10 \mathrm{v} / \mathrm{nl})$, live sperm $(\%)$, acrosome morphology defects (\%), acrosome detachment (\%) and acrosome abnormality (\%) in Hubbard white broiler breeder cocks. However, a single value of $3.58 \mathrm{~g}$ per $600 \mathrm{~g}$ DM feed significantly $(\mathrm{P}<0.05)$ supported optimum minimum acrosome abnormality in Hubbard white breeder broiler cocks. Thus,

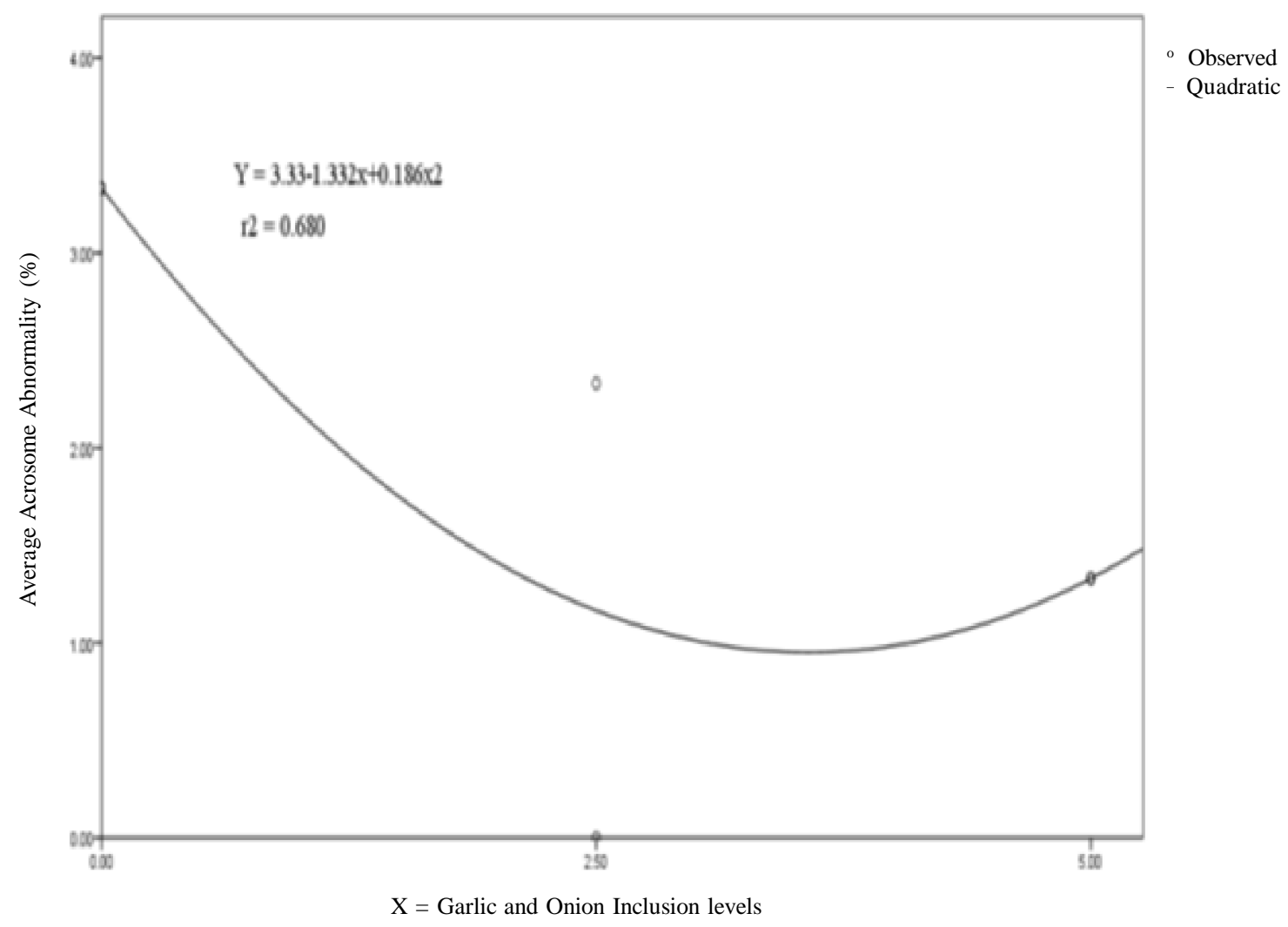

FIG 1: Effect of optimum inclusion of Garlic and Onion on acrsome abnormality defect of Hubbard white breeder cocks. 
Vol. Issue, ()

the implication of these findings is that optimizing onion and garlic inclusion level in the diet of Hubbard white broiler breeder cocks will depend on the semen quality

characteristics variable and could be helpful in enhancing their reproductive efficiency. Further studies are required to ascertain these findings.

\section{REFERENCES}

Ajayi, F.O., Agaviezor, B.O. and Ajuogu, K. (2011). Semen characteristics of three strains of local cocks in humid tropical environment of Nigeria. Int. J.Anim. Vet. Adv., 3:125-27.

Alabi O. J., Ng'ambi, J. W., Mbajiorgu, E. F., Norris, D. and Mabelebele, M. (2015). Growth and haematological response of indigenous Venda chicken aged 8-13 weeks to varying dietary lysine to energy ratios. J. of Animal Phys. and Anim Nutrition, 99: 436-441.

Alkan S., Baran, A., Ozdas, O. B. and Evecen, M. (2002). Morphological defects in turkey semen. Turk. J. Vet. Anim. Sci., 26: 1087-1092. Available online on: http://journals.tubitak.gov.tr/veterinary/issues/vet-02-26-5/vet-26-5-160107-40.pdf

Arzanlou M, and Bohlooli, S. (2010). Introducing of green garlic plant as a new source of allicin. Food chemistry, 120:179- 183 .

Atmaca, G. (2003). Antioxidative effects of garlic and some thiol - containing compounds. Trakya Univ. Ti. Fak. Dreg, 2:54-60.

Barkhordari, A., Hetmatimoghaddam, S., Ajebali, M., Khalili, A., Talebi, A. and Noorani, M. (2013). Effect of Zinc Oxide nanoparticle on viability of human spermatozoa. Iran Jour. Reprod. Med, 11:767-771.

Charkrabarti, B., Pal, S. and Bhattacharyya, A.K. (2003). Sperm immobilization activity of Allium sativa L. and other plant extracts. Asian J. of Andrology. 5:131-136.

Challa, A., Roa, D.R. and Reddy, B.S. (1997). Interactive suppression of aberrant cryptfoci induced by azoxymethane in rat colon by phytic acid and green tea. Carcinogenesi. 18: 2023-2026.

Dixit, V. and Joshi, S. (1983). Effects of chronic administration of garlic (Allium sativum .L.) on testicular function. Indian J. of experimental Biology. 2: 534-536.

Durrani, H.Z., Durrani, A. Z. and Kamal, N. (2010). Comparative efficacy of different therapeutic agents in experimentally induced Leishmaniasis in hamster. Jour. Plant Sci. 20: 13-16.

Egbunike, C.N. and Oluyemi, J.A. (1979). Comparative studies of the reproductive capacity of the Nigerian and exotic poultry breeds. Nig J. Anim. Prod. 6:47-51.

Elagib, H.A.A., Musharaf, N. A., Makawi, S. A. and Mohammed, H. E. (2012). The effects of age and season on semen characteristics of White leghorn cocks under Sudan condition. International J. poultry Sci. 11: 47-49.

Graffiths, G., Trueman, L., Crowther, T. and Thomas, B. (2002). Onion a global benefit of health. Phytother. Res. 17: 603-615.

Hafez, B and Hafez, E.S.E. (2000). Reproduction in farm Animals. $7^{\text {th }}$ ed. Lippincoh Williams and Wikkins, USA, New York.

Hammani, I., Nahdi, A., Mauduit, C., Benahmed, M. and Amri, M. (2008). The inhibitory effects on adult male reproductive functions of crude garlic (Allium Sativum) feeding. Asian J. of Andrology. 10: 593-601.

Hassanpour S., Saadaghian, M., Maheri, S. N., Eshratkhah, B. and ChaichiSemsari, M. (2011). Effect of condensed tannin on controlling faecal protein excretion in nematode-infected sheep in vivo study. Jour. Anim. Sci. 7: 896-900.

Hunt, C. D., Johnson, P. E., Herbel, J. and Mullen, L. K. (1992). Effects of dietary zinc depletion on seminal volume and zinc loss, serum testosterone concentrations, and sperm morphology in young men. Am. J. Clin. Nutr. 56: 148-157.

Izawa, H., Kohara, M., Aizawa, K., Suganuma, H., Inakuma, T., Watanabe, G., Taya, K. and Sugai, M. (2008). Alleviative effects of quercetin and onionon male reproductive toxicity induced by diesel exhaust particles. Biosci. Biotech. Biochem. 72: 1235-1241.

Kabir, M., Oni, O. O. and Akpa, G. N. (2007). Osborne selection index and semen traits interrelationships in Rhode Island Red and White breeder cocks. Int. J. Poult.Sci. 6: 999-1002.

Kasuga, S., Uda, N., Kyo, E., Ushijima, M. and Morihara, N. (2001). Pharmacologic activities of aged garlic extract in comparison with other garlic preparations. J. of Nutrition. 131: 10805- 10845.

Kemp B., Bakker, G. O. M., Denthartog, L. A. and Verstegen, M. W. A. (1991). The effect of semen collection frequency and food intake on semen production in breeding boars. Animal Production. 52: 355-360.

Khaki, A., Fathiazad, F., Nour, M. and Hamadeh, D.V.M. (2008). Evaluation of androgenic activity of allium cepa on spermatogenesis in the rat. Folia Morphologica. 68: 44-45.

Khaki, A., Fathiazard, F., Nouri, M., Khaki, A. A., Khamenehhi, H. J. and Hamadeh, M. (2009). Evaluation of androgenic activity of Allium cepa on spermatogenesis in the rat. Folia Morphol. 68: 45-51. 
Khaki, A., Farzadi, L., Ahmadi, S. and Ghadamkhair, E. (2011). Recovery of spermatogenesis by Allium cepa in Tocoplasmagondii infected rats. Afri. J. of Pharmacy and Pharmacology. 5: 903-907.

Khaki . A., Farnam, A., Davatgarbadil, A. and Nikniaz, H. (2012). Treatment effects of onion (allium cepa) and ginger (Zingiberofficinale) on sexual behavior of rat after inducing an antiepileptic drug (lamotrigine). Balkan Med Journ. 29: 236-242.

Kim, S., JO, S., Kwon, Y. and Hwong, J. (2011). Effect of onion (Allium cepa) extract administration on intestinal glucosidases activities and spikes in postprandid blood glucose levels in SD rats model. Int. Journ. Mol. Sci. 58: $213-220$.

Lake P. E. (1957). The male reproductive tract the fowl. J. Anat. 91: 116-129. PMID: 13405819.

Lee, B., Jung, J. and Kim, H. (2012). Assessment of red onion on antioxidant activity in rat. Food Chem. Toxicol. 50: 3912-3919.

Mbajiorgu, C. A. (2011). The response of male indigenous Venda chickens to diet energy to protein ratios fed from seven up to 13 weeks of age. J. of human ecology, 35: 161-166.

Mbajiorgu, C. A., Ng'ambi, J. W. N., Norris, D. and Alabi, O. J. (2011). Effect of dietary lysine to energy ratio on performance of unsexed indigenous Venda chickens. Asian J. of Animal and Veterinary Adv. 6: 517-524.

Murugesan, S., Matam, N., Kulkarni, R., Bhattacharya, T. K. and Chatterjee, R.N. (2013). Semen quality in white leghorn chicken select for egg production traits. Turk. J. Vet. Anim Sci., 37: 747-749.

Ogundun N. J., Mbajiorgu, E. F. and Mbajiorgu, C. A. (2013). Dose response effect of percentage Uromalt (M) Inclusion level on Spermatogenesis in West African Dwarf Buck Kids. Indian J. of Animal Research, 47: 373-378.

Oi, Y., Imafuku, M., Shishido, C., Kominate, Y. and Nishimuru, S. (2001). Garlic supplementation increases testicular testosterone and decreases plasmacorticosterone in rats fed a high protein diet. Jour. of Nutrition. 131: 2150-2156.

Peters, S.O., Shoyebo, O.O., Ilori, B. M., Ozoje, M. O., Ikeobi, C.O.N. and Adebambo, O.A. (2008). Semen quality traits of seven strain of chickens raised in the humid tropics. Int. J. Poult. Sci., 7: 949-953.

Raiz, A., Aleem, M. , Ijaz, A., Saeed, M. A. and Latiff, A. (2004). Effect of collection frequency on the semen quality of broiler breeder. Br. Poultry. Science. 45: 823-827

SAS. (2008). Statistical Analysis System. SAS User Guide: Release 9.2. SAS Institute, Cary NC.

Saeed, J. M. and Al-Soudi, K. A. (1975). Semen quality traits of seven strains of Chickens raised in the humid tropics. Anim. Vert. Adav. 7: 848-849.

Sahin K., Kucuk, O., Sahin, N. and Gursu, M. F. (2002). Optimal dietary concentration of vitamin E for alleviating the effect of heat stress on performance, thyroid status, $\mathrm{ACTH}$ and some serum metabolite and mineral concentrations in broilers. Vet. Med. - Czech. 47: 110-116.

Tarif, A.M., Bhuiyan, M. M. U., Ferdousy, R. N., Juyena, N. S. and Mollah, M. B. R. (2013) Evaluation of semen quality among four chicken lines. IOSR J.Agric. Vet. Sci. 6: 7-13.

Yama, O.E., Duru, F. I., Oremosu, A. A., Osinubi, A. A., Norohna, C. C., Okanlawon, A. O. (2011). Sperm quotient in Sprague-Dawley rats fed graded doses of seed extract of Momordicacharantia. Middle East Fertility Society Journal, 16: 154-158. 